\title{
Year Month Day Imputed
}

National Cancer Institute

\section{Source}

National Cancer Institute. Year Month Day Imputed. NCI Thesaurus. Code C81210.

An imputed date that includes the year, month and day of observation. 